\title{
A New Approach for Titration Calorimetric Data Analysis on the Binding of Magnesium Ion with Myelin Basic Protein
}

\author{
G. Rezaei Behbehani • A.A. Saboury • A. Fallah Baghery
}

Received: 11 February 2008 / Accepted: 11 March 2008 / Published online: 31 May 2008

(C) The Author(s) 2008

\begin{abstract}
The interaction of the myelin basic protein (MBP) from the bovine central nervous system with divalent magnesium ion was studied by isothermal titration calorimetry at $27^{\circ} \mathrm{C}$ in aqueous solution. A simple rapid method for determination of the dissociation binding constants for $\mathrm{Mg}^{2+}-\mathrm{MBP}$ interaction was introduced using the isothermal titration calometric data. The binding isotherm for $\mathrm{Mg}^{2+}-\mathrm{MBP}$ interaction is easily obtained by carrying out a titration calorimetric experiment using only one set of concentrations of MBP. There are two identical independent intrinsic association constants equal to $0.021 \mu \mathrm{mol} \cdot \mathrm{L}^{-1}$ in the first- and second-binding sites, respectively.
\end{abstract}

Keywords Myelin basic protein · Magnesium · Isothermal titration calorimetry · Binding parameters

\section{Introduction}

The energetics of biochemical reactions or molecular interactions at constant temperature are measured by Isothermal Titration Calorimetry (ITC) [1-3]. ITC gives invaluable information about biomacromolecule-ligand interactions. During the last two years we attempted to study the metal ion binding chemistry of different proteins [4-12]. They will change the conformational stability and form aggregates. The importance of metal ions such as $\mathrm{Ca}^{2+}$ and $\mathrm{Mg}^{2+}$ in determining the stability of proteins is widely reported [13-18]. There are some approximations in previous theories [18] which result in rough average values of binding parameters including a lot of errors. We have introduced a novel method which enables us to determine the binding parameters with minimal errors. This method is successfully applied to the analysis of $\mathrm{Mg}^{2+}$ binding MBP.

G. Rezaei Behbehani $(\bowtie)$

Chemistry Department, Imam Khomeini International University, Qazvin, Iran

e-mail: grb402003@yahoo.com

A.A. Saboury · A. Fallah Baghery

Institute of Biochemistry and Biophysics, University of Tehran, Tehran, Iran 


\section{Materials and Method}

\subsection{Materials}

MBP from bovine central systems (CNS) was obtained from Sigma Chemical Co. Magnesium nitrate was purchased from Merck Co. Protein concentrations were determined from absorbance measurements at $277 \mathrm{~nm}$ in $1 \mathrm{~cm}$ quartz cuvettes. All other materials and reagents were of analytical grade, and solutions were made from double-distilled water.

\subsection{Method}

The isothermal titration micro-calorimetric experiments were performed with the fourchannel commercial micro calorimetric system, Thermal Activity Monitor 2277, Thermometric, Sweden. The titration vessel was made from stainless steel. The magnesium nitrate solution $\left(500 \mu \mathrm{mol} \cdot \mathrm{L}^{-1}\right)$ was injected by use of a Hamilton syringe into the calorimetric titration vessel, which contained $1.8 \mathrm{~mL}$ MBP $\left(13.5 \mu \mathrm{mol} \cdot \mathrm{L}^{-1}\right)$. Thin $(0.15 \mathrm{~mm}$ inner diameter) stainless steel hypodermic needles, permanently fixed to the syringe, reached directly into the calorimetric vessel. Injection of magnesium nitrate solution into the perfusion vessel was repeated 30 times, with $30 \mu \mathrm{L}$ per injection. The calorimetric signal was measured by a digital voltmeter which was part of a computerized recording system. The heat of each injection was calculated by the "Thermometric Digitam 3" software program. The enthalpy of dilution of the magnesium solution was measured as described above except MBP was excluded. The enthalpies of dilution of the magnesium solutions were subtracted from the enthalpy of $\mathrm{Mg}^{2+}$-MBP interaction. The enthalpies of dilution of MBP are negligible. The micro calorimeter was frequently calibrated electrically during the course of the study. The molecular weight of MBP was taken to be $18500 \mathrm{Da}$. The enthalpies of $\mathrm{Mg}^{2+}-\mathrm{MBP}$ interactions were calculated in $\mathrm{kJ} \cdot \mathrm{mol}^{-1}$ and are shown in Fig. 1.

Fig. 1 Comparison between the experimental enthalpies, $\Delta H$, for $\mathrm{Mg}^{2+}$-MBP interactions (•) and calculated curve via Eq. 1.

$\left[\mathrm{Mg}^{2+}\right]_{\mathrm{T}}$ is the total concentration of $\mathrm{Mg}\left(\mathrm{NO}_{3}\right)_{2}$ solutions in $\mu \mathrm{mol} \cdot \mathrm{L}^{-1}$

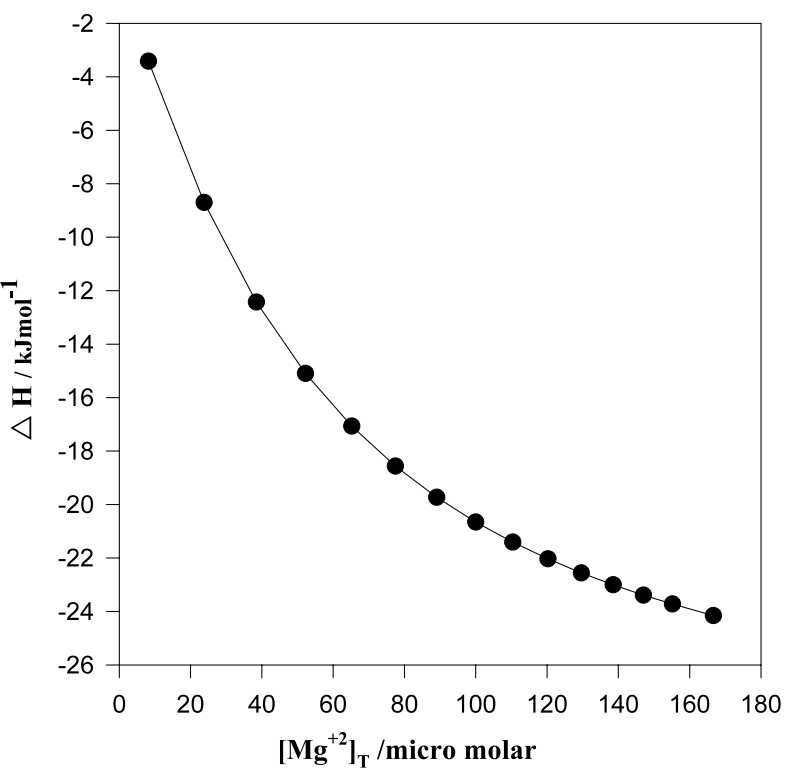




\section{Results and Discussion}

We have shown previously that the enthalpies of the solute-solvent $\left(\mathrm{Mg}^{2+}-\mathrm{MBP}\right.$-water in this case) interactions in the aqueous solvent $\left(\mathrm{Mg}^{2+}\right.$-water in the present case) system, can be accounted for quantitatively in terms of three factors: preferential solvation by the components of a mixed solvent, weakening or strengthening of solvent-solvent bonds by the solute and the change in the enthalpy of the solute-solvent interactions [19-28]. This treatment leads to:

$$
\Delta H=\Delta H_{\max } x_{\mathrm{B}}^{\prime}-\delta_{\mathrm{A}}^{\theta}\left(x_{\mathrm{A}}^{\prime} L_{\mathrm{A}}+x_{\mathrm{B}}^{\prime} L_{\mathrm{B}}\right)-\left(\delta_{\mathrm{B}}^{\theta}-\delta_{\mathrm{A}}^{\theta}\right)\left(x_{\mathrm{A}}^{\prime} L_{\mathrm{A}}+x_{\mathrm{B}}^{\prime} L_{\mathrm{B}}\right) x_{\mathrm{B}}^{\prime}
$$

The parameters $\delta_{\mathrm{A}}^{\theta}=(\alpha n+\beta N)_{\mathrm{A}}^{\theta}$ and $\delta_{\mathrm{B}}^{\theta}=(\alpha n+\beta N)_{\mathrm{B}}^{\theta}$ are the net effects of the solute (MBP in this case) on the water- $\mathrm{Mg}^{2+}$ bonds in the water-rich domain and $\mathrm{Mg}^{2+}$-rich region, respectively, with $\alpha n$ resulting from the formation of a cavity wherein $n$ solvent molecules become the nearest neighbors of the solute and $\beta N$ reflects the enthalpy change from strengthening or weakening of solvent-solvent bonds of $N$ solvent molecules $(N \geq n)$ around the cavity ( $\beta<0$ indicates a net strengthening of the solvent-solvent bonds). The constants $\alpha$ and $\beta$ represent the fraction of the enthalpy of water- $\mathrm{Mg}^{2+}$ interaction associated with cavity formation or restructuring, respectively. The superscript $\theta$ in all cases refers to the quantities at infinite dilution of the solute. $p<1$ or $p>1$ indicate a preference for water or $\mathrm{Mg}^{2+}$, respectively; $p=1$ indicates random solvation; and the $x_{\mathrm{B}}^{\prime}$ are the local mole fractions of the water and surfactant in the vicinity of the lysozyme or solvation sphere, where the solvent molecules are the nearest neighbors of the solute, which can be expressed as follows:

$$
x_{\mathrm{B}}^{\prime}=\frac{p x_{\mathrm{B}}}{x_{\mathrm{A}}+p x_{\mathrm{B}}}=\frac{v}{g}
$$

where $x_{\mathrm{A}}$ and $x_{\mathrm{B}}$ are bulk mole fractions and we can express them as the total $\mathrm{Mg}^{2+}$ concentration divided by the maximum concentration of $\mathrm{Mg}^{2+}$ upon saturation of all MBP as follows:

$$
x_{\mathrm{B}}=\frac{\left[\mathrm{Mg}^{2+}\right]_{\mathrm{T}}}{\left[\mathrm{Mg}^{2+}\right]_{\max }}, \quad x_{\mathrm{A}}=1-x_{\mathrm{B}}
$$

$\left[\mathrm{Mg}^{2+}\right]_{\mathrm{T}}$ is the total concentration of surfactant and $\left[\mathrm{Mg}^{2+}\right]_{\max }$ is the maximum concentration of the $\mathrm{Mg}^{2+}$ upon saturation with respect to MBP. In general, there will be " $g$ " sites for binding of $\mathrm{Mg}^{2+}$ per MBP molecule and $v$ is defined as the average moles of bound $\mathrm{Mg}^{2+}$ per mole of total MBP. $L_{\mathrm{A}}$ and $L_{\mathrm{B}}$ are the relative partial molar enthalpies and can be calculated from heats of dilution of $\mathrm{Mg}^{2+}$ in water, $\Delta H_{\text {dilut }}$, as follows:

$$
L_{\mathrm{A}}=\Delta H_{\text {dilut }}+x_{\mathrm{B}}\left(\frac{\partial \Delta H_{\text {dilut }}}{\partial x_{\mathrm{B}}}\right), \quad L_{\mathrm{B}}=\Delta H_{\text {dilut }}+x_{\mathrm{A}}\left(\frac{\partial \Delta H_{\text {dilut }}}{\partial x_{\mathrm{B}}}\right)
$$

The enthalpies of $\mathrm{Mg}^{2+}$-MBP interactions, $\Delta H$, were fitted by Eq. 1 over the whole range of $\mathrm{Mg}^{2+}$ compositions. In this procedure the only adjustable parameter, $p$, was changed until the best agreement between the experimental and calculated data was approached over the whole range of solvent compositions (Fig. 1). Thermodynamic parameters for $\mathrm{Mg}^{2+}$ MBP interactions recovered from Eq. 1 are listed in Table 1. The experimental enthalpies of $\mathrm{Mg}^{2+}-\mathrm{MBP}$ interactions and calculated data from Eq. 1 are compared in Fig. 1. The agreement between the experimental enthalpies and calculated data via Eq. 1 provides good support for this equation. 
Table 1 Thermodynamic parameters for $\mathrm{Mg}^{2+}-\mathrm{MBP}$ interactions recovered from Eq. 1. $\Delta \Delta H_{12}<0$ indicates that the interaction of the MBP with $\mathrm{Mg}^{2+}$ is stronger than with water. The precision is \pm 0.005 or better

\begin{tabular}{llccc}
\hline$[\mathrm{MBP}] \mu \mathrm{mol} \cdot \mathrm{L}^{-1}$ & $p$ & $\delta_{\mathrm{A}}^{o}$ & $\delta_{\mathrm{B}}^{o}$ & $\Delta \Delta H_{12}$ \\
\hline 13.5 & 5.005 & 0.434 & 0.476 & -17.774 \\
\hline
\end{tabular}

$\varphi$ is the fraction of MBP molecule undergoing complexation with $\mathrm{Mg}^{2+}$ which can be expressed as follows:

$$
\varphi=\frac{\left(\Delta H_{\mathrm{W}}-\Delta H\right)}{\left(\Delta H_{\mathrm{W}}-\Delta H_{\mathrm{max}}\right)}
$$

where $\Delta H_{\mathrm{W}}$ is the enthalpy of $\mathrm{Mg}^{2+}-\mathrm{MBP}$ interactions in the water-rich domain and $\Delta H_{\max }=\Delta \Delta H_{12}^{\mathrm{o}}+\delta_{\mathrm{B}}^{\mathrm{o}} \Delta H_{\mathrm{Mg}\left(\mathrm{NO}_{3}\right)_{2}}^{\mathrm{S}}-\delta_{\mathrm{A}}^{\mathrm{o}} \Delta H_{\mathrm{W}}^{\mathrm{o}^{*}}$ represents the heat value upon saturation of all MBP. $\Delta \Delta H_{12}^{\mathrm{o}}$ is the difference between the enthalpies of the $\mathrm{Mg}^{2+}$-MBP and water-MBP interactions. $\Delta \Delta H_{12}>0$ indicates that the interaction of the MBP with $\mathrm{Mg}^{2+}$ is weaker than with water. $\Delta H_{\mathrm{W}}^{\mathrm{o}^{*}}$ is the enthalpy of condensation of pure water $\left(-44.700 \mathrm{~kJ} \cdot \mathrm{mol}^{-1}\right)$ and $\Delta H_{\mathrm{Mg}\left(\mathrm{NO}_{3}\right)_{2}}^{\mathrm{S}}$ is the enthalpy of solution of magnesium nitrate in water $\left(-3.400 \mathrm{~kJ} \cdot \mathrm{mol}^{-1}\right)$. The equilibrium constant values, $K_{\mathrm{d}}$, as a function of $\mathrm{Mg}^{2+}$ concentration can be calculated as follows:

$$
K_{\mathrm{d}}=\frac{\varphi}{1-\varphi}
$$

The equilibrium constants, $K_{\mathrm{d}}$, for successive replacement of the $\mathrm{Mg}^{2+}$ ions by water molecules are as follows:

$$
K_{\mathrm{d}}=x_{\mathrm{A}}^{g}-\sum_{i=1}^{g} \beta_{i}^{\prime} \frac{x_{\mathrm{B}}^{i}}{x_{\mathrm{A}}^{i-g}}
$$

In fact the $K_{\mathrm{d}}$ values are the equilibrium constants for the equilibria:

$$
\begin{gathered}
\operatorname{MBP}\left(\mathrm{H}_{2} \mathrm{O}\right)_{g-i}\left(\mathrm{Mg}^{2+}\right)_{i}+i \mathrm{H}_{2} \mathrm{O} \rightleftharpoons \mathrm{MBP}\left(\mathrm{H}_{2} \mathrm{O}\right)_{g}+i \mathrm{Mg}^{2+}, \\
K_{\mathrm{d}}=\frac{\left[\mathrm{MBP}\left(\mathrm{H}_{2} \mathrm{O}\right)_{g}\right]\left[\mathrm{Mg}^{2+}\right]^{i}}{\left[\mathrm{MBP}\left(\mathrm{H}_{2} \mathrm{O}\right)_{g-i}\left(\mathrm{Mg}^{2+}\right)_{i}\right]}
\end{gathered}
$$

The $K_{\mathrm{d}}$ values obtained from Eq. 6, were fitted by Eq. 7 using a computer program for nonlinear least-squares fitting. Therefore, we can approximate the " $g$ " value simply as $g=2$ in this work. The $\beta_{i}^{\prime}$ values are the equilibrium products for the equilibria E1. Finally, the $v$ values can be calculated at any concentration of $\mathrm{Mg}^{2+}$ via Eq. 3. The binding parameters obtained from this method are listed in Tables 2 and 3 and shown graphically in Figs. 2 and 3. The Gibbs energies as a function of the $\mathrm{Mg}^{2+}$ concentration can be obtained as follows:

$$
\Delta G=-R T \ln K_{\mathrm{a}}
$$

where $K_{\mathrm{a}}$ is the association equilibrium constant $\left(1 / K_{\mathrm{d}}\right)$ as a function of $\mathrm{Mg}^{2+}$ concentration. Gibbs energies, $\Delta G$, calculated from Eq. 8 are shown graphically in Fig. 4. The $\Delta S$ values were calculated using the $\Delta G$ values and are shown in Fig. 5. Therefore, for the first 
Table $2 \beta_{i}^{\prime}$ 's values recovered from the coefficients of Eq. 7, for 2 individual sites of MBP

Table $3 \quad K_{\mathrm{d}}$ and $v$ values as a function of $\mathrm{Mg}^{2+}$ concentrations for $\mathrm{Mg}^{2+}-\mathrm{MBP}$ interactions. The precisions are \pm 0.005 or better

\begin{tabular}{ll}
\hline Number of sites & $\beta_{i}^{\prime} / \mu \mathrm{mol} \cdot \mathrm{L}^{-1}$ \\
\hline 1 & $3.272 \pm 0.026$ \\
2 & $3.383 \pm 0.013$ \\
\hline
\end{tabular}

\begin{tabular}{rll}
\hline$\left[\mathrm{Mg}^{+2}\right] \mathrm{T} / \mu \mathrm{mol} \cdot \mathrm{L}^{-1}$ & $K / \mu \mathrm{mol} \cdot \mathrm{L}^{-1}$ & $v$ \\
\hline 8.197 & 0 & 0.411 \\
23.809 & 0.342 & 0.909 \\
52.239 & 0.768 & 1.200 \\
65.217 & 1.289 & 1.391 \\
77.465 & 1.927 & 1.526 \\
89.041 & 2.710 & 1.626 \\
100.000 & 3.686 & 1.703 \\
110.389 & 4.927 & 1.765 \\
120.253 & 6.564 & 1.815 \\
129.626 & 8.784 & 1.857 \\
138.554 & 12.015 & 1.892 \\
147.059 & 17.060 & 1.922 \\
155.172 & 26.209 & 1.948 \\
166.667 & 47.441 & 1.970 \\
\hline
\end{tabular}

Fig. 2 The experimental dissociation constants $(\square), K_{\mathrm{d}}$, via Eq. 6 and calculated curve for $\mathrm{Mg}^{2+}$-MBP interactions (in $\mu \mathrm{mol} \cdot \mathrm{L}^{-1}$ ) against the $\mathrm{Mg}^{2+}$ concentrations $\left(\mu \mathrm{mol} \cdot \mathrm{L}^{-1}\right)$ via Eq. 7

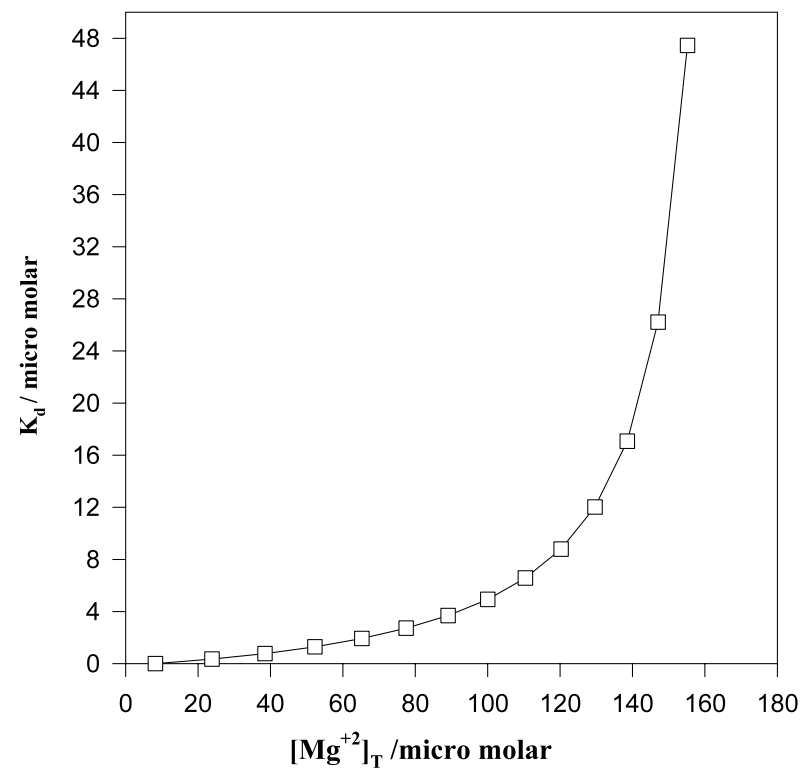

time, we managed to calculate $\Delta G$ and $\Delta S$ values using one set of experimental data at one temperature. 
Fig. $3 v$ values for $\mathrm{Mg}^{2+}-\mathrm{MBP}$ interactions $\left(\mu \mathrm{mol} \cdot \mathrm{L}^{-1}\right)$ against the $K_{\mathrm{d}}\left(\mu \mathrm{mol} \cdot \mathrm{L}^{-1}\right)$
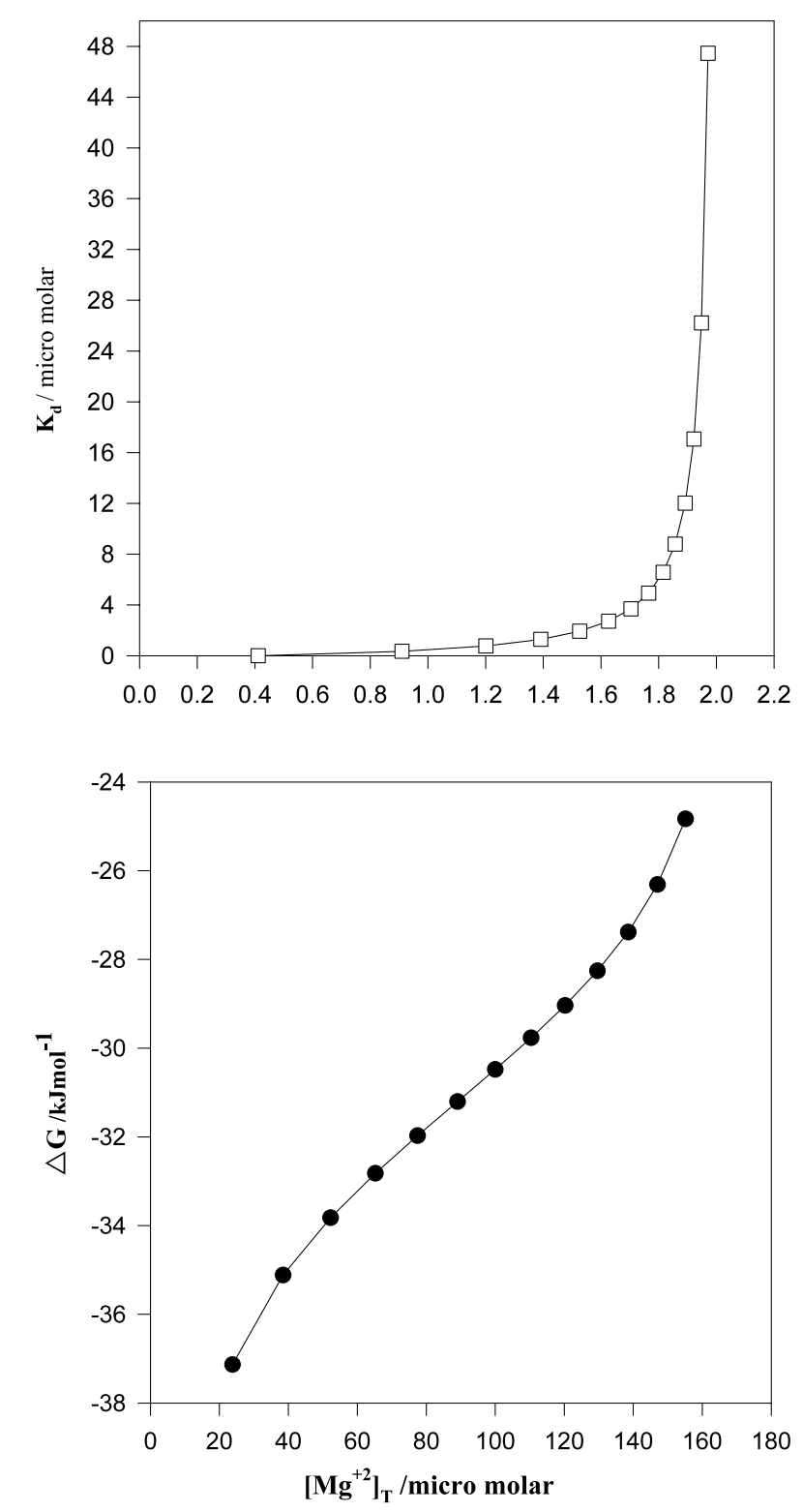

Fig. 4 The experimental $\Delta G$ values $(\bullet)$ via Eqs. 6 and 8 $\left(\mathrm{kJ} \cdot \mathrm{mol}^{-1}\right)$ and the calculated data from Eqs. 7 and 8 (curves) for $\mathrm{Mg}^{2+}-\mathrm{MBP}$ interactions against the $\mathrm{Mg}^{2+}$ concentrations $\left(\mu \mathrm{mol} \cdot \mathrm{L}^{-1}\right)$

If the multiple binding sites on a macromolecule are identical and independent, the ligand binding sites can be reproduced by a model system of monovalent molecules ((MBP) $\rightarrow$ $g \mathrm{MBP})$ with the same set of dissociation constant, $\left(K_{\mathrm{d}}\right)_{\max }$, values. Setting $g=i$ in Eq. E1, leads to:

$$
\begin{gathered}
\mathrm{MBP}\left(\mathrm{Mg}^{2+}\right)_{g}+g \mathrm{H}_{2} \mathrm{O} \rightleftharpoons \mathrm{MBP}\left(\mathrm{H}_{2} \mathrm{O}\right)_{g}+g \mathrm{Mg}^{2+}, \\
\left(K_{\mathrm{d}}\right)_{\max }=\frac{\left[\mathrm{MBP}\left(\mathrm{H}_{2} \mathrm{O}\right)_{g}\right]\left[\mathrm{Mg}^{2+}\right]^{g}}{\left[\mathrm{MBP}\left(\mathrm{Mg}^{2+}\right)_{g}\right]\left[\mathrm{H}_{2} \mathrm{O}\right]^{g}}
\end{gathered}
$$


Fig. 5 The experimental $\Delta S$ values $(\bullet)$ and calculated curve for $\mathrm{Mg}^{2+}$-MBP interactions $\left(\mathrm{kJ} \cdot \mathrm{mol}^{-1}\right)$ against the $\mathrm{Mg}^{2+}$ concentration $\left(\mu \mathrm{mol} \cdot \mathrm{L}^{-1}\right)$

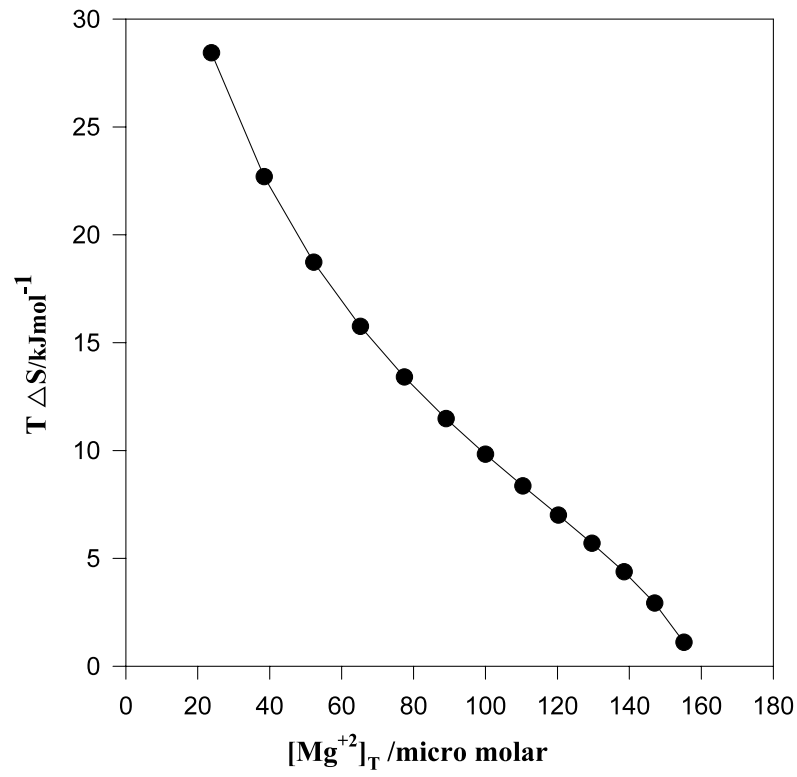

Equilibrium E2 is a special case of the equilibrium E1 in the $\mathrm{Mg}^{2+}$-rich domain where MBP is saturated by $\mathrm{Mg}^{2+}$ ions. In other words, the $\left(K_{\mathrm{d}}\right)_{\max }$ value corresponds to the point where $x_{\mathrm{B}}^{\prime}=1$ (or the maximum $v$ value) (Fig. 3 ) and can be calculated easily. Binding parameters for the $\mathrm{Mg}^{2+}-\mathrm{MBP}$ interactions using the new model are as follows:

$$
\left(K_{\mathrm{d}}\right)_{\max }=47.44 \mu \mathrm{mol} \cdot \mathrm{L}^{-1} \quad \Delta H=-15.10 \mathrm{~kJ} \cdot \mathrm{mol}^{-1} \quad g=2
$$

As we have reported previously, the free concentration of ligand, $\left[\mathrm{Mg}^{2+}\right]_{\mathrm{F}}$, can be calculated as follows:

$$
\left[\mathrm{Mg}^{2+}\right]_{\mathrm{F}}=\left[\mathrm{Mg}^{2+}\right]_{\mathrm{T}}-v[\mathrm{MBP}]_{\mathrm{T}}
$$

The association binding constant, $K_{\mathrm{a}}$, can be obtained from the Scatchard equation as follows:

$$
\frac{v}{g-v}=K_{\mathrm{a}}\left[\mathrm{Mg}^{2+}\right]_{\mathrm{F}}
$$

The association constant for the $\mathrm{Mg}^{2+}-\mathrm{MBP}$ interaction obtained from Eq. 10 is $0.021 \mu \mathrm{mol} \cdot \mathrm{L}^{-1}\left(K_{\mathrm{d}}=47.62 \mu \mathrm{mol} \cdot \mathrm{L}^{-1}\right)[27,28]$, which is in good agreement with the $\left(K_{\mathrm{d}}\right)_{\max }$ value calculated from Eqs. 6 and 7. Equation 10 gives us the maximum value for $K_{\mathrm{d}}$, but Eqs. 6 and 7 allows us to have the $K_{\mathrm{d}}$ values at every concentration of $\mathrm{Mg}^{2+}$ ions.

Figure 2 shows the dissociation constant as a function of the total concentration of $\mathrm{Mg}^{2+}$. The low $K_{\mathrm{d}}$ values in the water-rich domain reflect the higher affinity of MBP for $\mathrm{Mg}^{2+}$ in this domain which is in agreement with the $\Delta \Delta H_{12}$ value (Table 1). In the $\mathrm{Mg}^{2+}$-rich domain the slope of the curve in Fig. 2 varies sharply, indicating a lower affinity of MBP for $\mathrm{Mg}^{2+}$ in this region. The shallow slope of $v$ against $K_{\mathrm{d}}$ (Fig. 3), corresponds to the higher affinity of MBP in the water-rich domain followed by the steep slope which indicates a lower affinity of MBP in the $\mathrm{Mg}^{2+}$-rich domain. The negative Gibbs energies in the waterrich domain (Fig. 4) also indicate the higher affinity in this region. 
We will arrive at the same conclusion using the solvation parameters recovered from Eq. 1 (Table 2). The $\delta_{\mathrm{A}}^{\theta}$ values reflect to the hydrophobic hydration of MBP, leading to the enhancement of the water structure. The greater the extent of this enhancement, the greater the stabilization of the MBP structure and the greater the $\delta_{\mathrm{A}}^{\theta}$ value and vise versa. In the $\mathrm{Mg}^{2+}$-rich region the $\delta_{\mathrm{B}}^{\theta}$ value is more positive (0.476) than that in water-rich domain, indicating that the $\mathrm{Mg}^{2+}$-MBP complex is more stable (lower affinity) in the $\mathrm{Mg}^{2+}$-rich region in comparison to the water-rich domain. The $p$ value (5.005) shows the preferential tendency of $\mathrm{Mg}^{2+}$ for occupying the available sites on MBP.

Acknowledgements Financial support from the Universities of Imam Khomeini (Qazvin) and Tehran and the Iranian National Science Foundation (INSF) are gratefully acknowledged.

Open Access This article is distributed under the terms of the Creative Commons Attribution Noncommercial License which permits any noncommercial use, distribution, and reproduction in any medium, provided the original author(s) and source are credited.

\section{References}

1. Saboury, A.A.: A review on the ligand binding studies by isothermal titration calorimetry. J. Iran. Chem. Soc. 3, 1-21 (2006)

2. Saboury, A.A.: New methods for data analysis of isothermal titration calorimetry. J. Therm. Anal. Cal. 72, 93-103 (2003)

3. Saboury, A.A.: A simple method for determination of binding isotherm by isothermal titration calorimetry and its application to the interaction between $\mathrm{Cu}^{2+}$ and myelin basic protein. J. Therm. Anal. Cal. 77, 997-1004 (2004)

4. Ataie, G., Moosavi-Movahedi, A.A., Saboury, A.A., Hakimelahi, G.H., Hwu, J.R., Tsay, S.C.: The enthalpy and enzyme activity of modified histidine residues of adenosine deaminase and diethyl pyrocarbonate complexes. Int. J. Biol. Macromol. 27, 29-33 (2000)

5. Saboury, A.A., Atri, M.S., Sanati, M.H., Sadeghi, M.: Application of a simple calorimetric data analysis on the binding study of calcium ions by human growth hormone. J. Therm. Anal. Cal. 83, 175-179 (2006)

6. Saboury, A.A., Atri, M.S., Sanati, M.H., Moosavi-Movahedi, A.A., Hakimelahi, G.H., Sadeghi, M.: Thermodynamic study on the interaction between magnesium ion and human growth hormone. Biopolymers 81, 120-126 (2006)

7. Saboury, A.A., Atri, M.S., Sanati, M.H., Moosavi-Movahedi, A.A., Haghbeen, K.: Effects of calcium binding on the structure and stability of human growth hormone. Int. J. Biol. Macromol. 36, 305-309 (2005)

8. Saboury, A.A., Kordbacheh, M., Sanati, M.H., Mizani, F., Shamsipur, M., Yakhchali, M.B., MoosaviMovahedi, A.A.: Thermodynamics of binding copper ion by human growth hormone. Asian J. Chem. 17, 2773-2782 (2005)

9. Atri, M.S., Saboury, A.A., Rezaei-Tavirani, M., Sanati, M.H., Moosavi-Movahedi, A.A., Sadeghi, M., Mansuri-Torshizi, H., Khodabandeh, N.: Binding properties and conformational change of human growth hormone upon interaction with $\mathrm{Fe}^{+3}$. Thermochim. Acta 438, 178-183 (2005)

10. Saboury, A.A., Ghourchaei, H., Sanati, M.H., Atri, M.S., Rezaei-Tawirani, M., Hakimelahi, G.H.: Application of a simple calorimetric data analysis on the binding study of calcium ions by human growth hormone. J. Therm. Anal. Cal. 83, 175-179 (2006)

11. Hindmarsh, P.C., Brook, C.G.: Effect of growth hormone on short normal children. Br. Med. J. (Clin. Res. Ed.) 295, 573-583 (1987)

12. de Voc, A.M., Ultsch, M., Kossiakoff, A.A.: Human growth hormone and extracellular domain of its receptor: Crystal structure of the complex. Science 255, 306-402 (1992)

13. Filikov, A.V., Hayes, R.J., Luo, P., Stark, D.M., Chan, C., Kundu, A., Dahiyat, B.I.: Structural plasticity in a remodeled protein-protein interface. Protein Sci. 11, 1452-1461 (2002)

14. Arakawa, T., Timasheff, S.N.: Mechanism of protein salting in and salting out by divalent cation salts: balance between hydration and salt binding. Biochem. 23, 5912-5923 (1984)

15. MacLean, D.S., Qian, O.S., Middaugh, C.R.: Stabilization of proteins by low molecular weight multiions. J. Pharm. Sci. 91, 2220-2229 (2002) 
16. Nishimura, C., Uversky, V.N., Fink, A.L.: The effect of salts on the stability and folding of staphylococcal nuclease. Biochem. 40, 2113-2128 (2001)

17. Curtis, R.A., Ulrich, J., Montaser, A., Blanch, H.W.: Protein-protein interactions in concentrated electrolyte solutions. Hofmeister-series effects. Biotechnol. Bioeng. 79, 367-380 (2002)

18. Bordbar, A.K., Saboury, A.A., Housaindokht, M.R., Moosavi-Movahedi, A.A.: Statistical effects of the binding of ionic surfactant to protein. J. Coll. Interface Sci. 192, 415-419 (1997)

19. Rezaei Behbehani, G.: Application of a new method to reproduce the enthalpies of transfer of NaI from water to aqueous methanol, ethanol and $i \mathrm{PrOH}$ solvent systems at $289.15 \mathrm{~K}$. J. Bull. Korean Chem. Soc. 2, 238-240 (2005)

20. Rezaei Behbehani, G.: Application of the new solvation theory to reproduce the enthalpies of transfer of $\mathrm{LiBr}$, tetrabuthylammonium bromide and tetrapenthylamonium bromide from water to aqueous acetonitrile at 298 K. Acta Chim. Slovak. 52, 282-285 (2005)

21. Rezaei Behbehani, G., Tazikeh, E., Saboury, A.A.: Using the new developed equation to reproduce the enthalpies of transfer of urea from water to aqueous ethanol, propan-1-ol and acetonitrile at $298 \mathrm{~K}$. J. Bull. Korean Chem. Soc. 2, 208-210 (2006)

22. Rezaei Behbehani, G., Ghamamy, S.: Enthalpies of transfer of formamide, N-methylformamide and $\mathrm{N}, \mathrm{N}$-dimethylformamide from water to aqueous acetonitrile mixtures at $298 \mathrm{~K}$. Thermochim. Acta 444, 71-76 (2006)

23. Rezaei Behbehani, G., Ghamamy, S., Waghorne, W.E.: Enthalpies of transfer of acetonitrile from water to aqueous methanol, ethanol and dimethyl sulphoxide mixtures at $298.15 \mathrm{~K}$. J. Thermochim. Acta 448 , 37-42 (2006)

24. Rezaei Behbehani, G., Tazikeh, E., Saboury, A.A.: Using the Extension Coordination Model (ECM) to reproduce the enthalpies of transfer of tetraethylurea from water to aqueous ethanol, propan-1-ol and acetonitrile at 298 K. Acta Chim. Slovak. 53, 363-369 (2006)

25. Rezaei Behbehani, G., Saboury, A.A.: Using a new solvation model for thermodynamic study on the interaction of nickel with human growth hormone. Thermochim. Acta 452, 76-79 (2007)

26. Reza Bebahani, G., Dunnion, D., Falvey, P., Hickey, K., Meade, M., McCarthy, Y., Symons, M.C.R., Waghorne, W.E.: Nonelectrolyte solvation in aqueous dimethyl sulfoxide-A calorimetric and infrared spectroscopic study. J. Solution Chem. 29, 521-539 (2000)

27. Rezaei Behbehani, G., Saboury, A.A.: A new method for thermodynamic study on the binding of magnesium with human growth hormone. J. Therm. Anal. Cal. 89, 852-861 (2007)

28. Rezaei-Behbehani, G., Saboury, A.A., Bagheri, A.F.: A thermodynamic study on the binding of calcium ion with myelin basic protein. J. Solution Chem. 36, 1311-1320 (2007) 